\title{
A Chi-Square Application on the Factors Influencing Internet Banking Adoption (IBA) and Usage in Botswana
}

\author{
Nehemiah Mavetera \\ North West University \\ Nehemiah.mavetera@nwu.ac.za \\ Ntebogang Dinah Moroke \\ North West University \\ Ntebo.moroke@nwu.ac.za \\ Chengetai Chibonda \\ North West University \\ cchibonda@yahoo.com
}

Doi:10.5901/mjss.2014.v5n20p596

\section{Abstract}

There exists a myriad of studies on technology acceptance theories that have been used to study the adoption of Internet banking services world over. However, Technology acceptance model (TAM) has gained wide popularity compared to other behavioral theories. This study uses some constructs from TAM and IDT to investigate the factors that influence IBA in Botswana's Gaborone city working class and college students. A quantitative research study approach, using a questionnaire as the research instrument was adopted. The study notes that among other factors, PEOU, PU and trust have a significant influence on IBA. The study also notes that IB awareness and resources must be increased for them to contribute significantly to the positive adoption rates of IB in Botswana. Lastly, instead of taking a confirmatory approach to behavioral studies like this one, the authors would like to suggest that an exploratory study maybe more appropriate with structural equation modeling as the preferred analysis technique. This can reveal more insights into the data. However, if this is to be done, the sample size needs to be increased. Sample size is one of the weakness of this study hence we cannot generalize the findings to the whole of Botswana.

Keywords: Adoption, Internet Banking, Technology acceptance model (TAM), Botswana, Innovation diffusion theory

\section{Introduction}

Technology plays a major role in the world of business, especially the banking sector. Amongst the newest delivery channels for banking services recently introduced is electronic banking (e-banking). This, according to Daniel (1999); Mols (1998) and Sathye (1999) refers to several types of services through which bank customers can request information and carry out most retail banking services via the computer, television or mobile phones. These services are available to customers twenty four hours a day and seven days (24/7) a week. When using these services, customers can do their daily banking activities without having to move from one place to the other, no queuing on the line or calling a call center. Customers are at liberty to serve themselves whenever and wherever they wish. Application for loans, paying bills, transfer of funds, balance enquiries, obtaining information about one's account, trading, etc. has been simplified quite significantly.

Internet banking is used by banks as one of their distribution channels. This service benefits both the banks and their customers and it has become the most profitable distribution channel (Karjaluoto 2002). Both parties can save on costs because of this service. Rotchanakitumnuai and Speece (2004) noted that IB is being implemented quickly by many companies in the financial services sector. However, while this channel has been necessitated by the availability of the Internet, not all has been going well with this distribution channel.

For example, TechWeb news (2005) (www.techweb.com) reported on the problems encountered during the bursting of the internet bubble which took place from the mid-1990s up to 2001. During this period, many businesses 
struggled for survival and some dropped electronic channels completely, but internet banking recovered quickly and has been on a steady growth in some developed countries such as Australia. Banks adopted internet banking to gain a competitive edge, improve distribution and delivery management, while some waited to see if the early adopters would succeed. Technological development in computing and communications also catalyzed the e-banking adoption process (Jayawardhena \& Foley 2000). Customer demands have also risen and banks cannot afford to rest on their laurels. Some new entrants into banking came very technologically sharpened prompting many traditional banks to adjust quickly, otherwise they were set to lose their market share.

This study analyzed the adoption of internet banking in Gaborone's working class and the university students. Gaborone is a capital city of Botswana, one of the smallest countries in terms of population in Sothern Africa. This country has ten banks with branches all over the country's towns and villages. Four of the main banks such as Standard Chartered Bank, Stanbic Bank, First National Bank and Barclays Bank take more than $94 \%$ of the market share. The rest of the other banks are commercial and have been in operation for less than ten years. Since year 2000, Botswana had 15000 internet users. This increased to over 167000 in 2011. The government has liberalized the internet market in the past five years and this gave birth to many internet service providers of which 30 are licensed. Connectivity has improved with the country's access to the international bandwidth through the optic fiber backbone network and new submarine fiber optic cables off Africa's east and west coasts. Broadband internet is now widely available in the country.

Despite the availability of internet facilities in Botswana, Internet banking is still in its infancy as seen on the banks' websites and brochures. The services which are generally offered include checking balances, obtaining statements, transfers and deposits. Some banks are tirelessly trying to encourage customers to use this facility but the adoption is at a very slow rate. This study will among other issues, investigate the rate at which internet banking is adopted in Gaborone. Six factors that affect internet banking adoption, that is, demographics, perceived usefulness (PU), perceived ease of use (PEOU), awareness, compatibility, and trust were used. The study aims to advance the understanding and application of IBA theories such as TAM and IDT as well as understanding issues that impact on IB technologies.

The remainder of this paper is as follows: related literature on IBA is discussed next, followed by the methodology used in this study. The research findings are discussed together with their implications for theory and practice and lastly, the paper concludes by citing some highlights for further research.

\section{Literature Review}

To date, many studies investigating the factors that affect internet banking adoption have been conducted. These studies used different social behavioral theories and models such as agency theory (Ross, 1973), Theory of Planned behavior (Azjen, 1991), TAM and IDT (Davis, 1989 and Rogers, 1962). Citing an example, Lichtenstein and Williamson (2006) used Mass Media Theories (MMT) through individual and focus group discussions to determine the attitudes of people on internet banking adoption. The results of this study showed that older people with low income in Australia lacked knowledge of internet banking and its advantages. Other factors that hindered the adoption of this service were reported to be a lack of internet access and confidence, inadequate knowledge and support to use the service, lack of trust as well as security and privacy risks.

The Turkey et al. (2010) study reported security and reliability to be among the major factors that influence internet banking adoption. However, other factors such as infrastructural competencies and user-friendliness, 20 and 45 level of education and socioeconomic class determined the level of internet access among people.

In another study, Ainin et al. (2005) adapted a Website Evaluation Model (WEM) by Chung and Payter (2002). Their study took into consideration the information, legal statement, order, ease of use, aesthetic effects, performance and characteristics of the bank that provide internet banking. The results showed that there is a negative significant relationship between age and internet banking adoption among Klang Valley adopters. It was also revealed that respondents' monthly gross income and their job satisfaction have a positive significant relationship with internet banking adoption among Klang Valley adopters. However, gender, marital status, ethnic group, level of education did not reveal a significant relationship with internet banking adoption.

The study conducted by Khalil and Pearson (2007) was based on the innovation diffusion theory (IDT) developed by Rogers (1962). This study focused on five key issues called innovation characteristics of belief (relative advantage, comparability, complexity, trial ability and observability) and trust. It is noted that all innovation characteristics except complexity are positively correlated to innovation adoption. The aim of this study was to explore the intension to use internet banking among university students. Structural equation modeling (SEM) was used and the results showed that trust, relative advantage and trial ability had a significant influence on attitude. Ndubisi and Sinti (2006) conducted similar study and adopted the IDT, trust and motivation theories through an online survey method. The results of this study 
revealed that four factors namely, importance of internet to banking needs, compatibility, complexity, trial ability and risk accounted for $38 \%$ of the variance of internet banking adoption. Comparability was the only variable found not to be a significant predictor of internet banking adoption. Other set of variables such as internet experience, education level and frequency of usage of banking services were not good predictors of internet banking adoption.

Davis (1986) introduced Technology Acceptance Model (TAM) with the aim of understanding and predicting the process of user acceptance or adoption of information systems. This is the most cited and adopted theoretical framework in the area of information technology (IT) adoption. Taylor and Todd (1995) noted that TAM has been evaluated and proved to be a powerful and parsimonious model for representing the determinants of system usage but also valuable tool for system planning since system designers have some degree of control over easiness and usefulness. This model hypothesizes that perceived ease of use (PEOU) and perceived usefulness (PU) of technology are predictors of user attitude towards using the technology, subsequent behavioral intentions and actual usage. PEU is also hypothesized to affect attitudes and PU. PU is defined as the degree to which people believe that using a system will increase or improve their performance. Davis et al. (1989) refer to PEOU as the extent to which people believe that using a system will be free of effort. PU has a direct influence on intention to use while PEOU indirectly affect PU and attitude on the behavioral intention. Behavioural intention is a measure of the strength of a person's willingness to extent effort while performing certain behaviors. Attitude explains the person's favorable or unfavorable assessment regarding the behavior in question. The next section discusses the research framework used and the hypotheses used in this study.

\section{The Model and Hypotheses}

\subsection{The model}

This study integrates the TAM and IDT constructs to build the IBA model that was used to analyse the adoption of internet banking by Gaborone's working class and university students. Two constructs from TAM; PU and PEOU and three constructs from IDT; awareness, compatibility and trust were used. All these are independent variables. Attitude towards using the technology, subsequent behavioral intentions and actual usage serve as surrogate variables for IBA. Some adjustments have been made so that the framework is more specific to Internet Banking Adoption. The model is shown graphically in Figure 1:

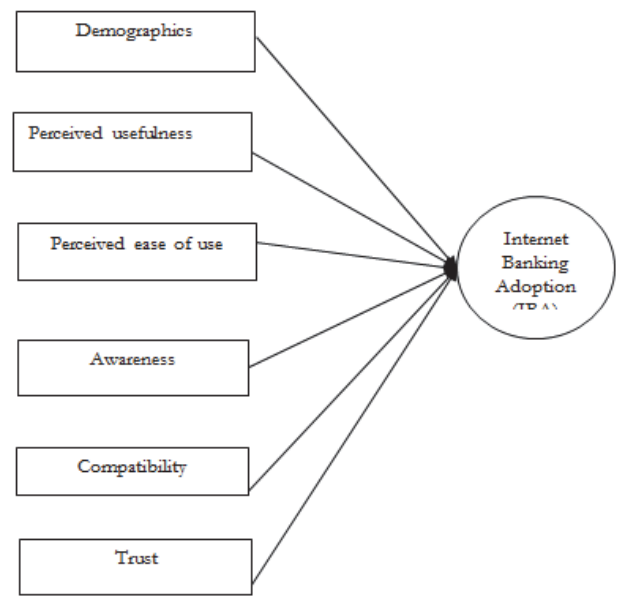

Figure 1: Research Framework

\subsection{Hypotheses Development}

This study proposed the following hypotheses based on the conceptual model shown in Figure 1.

\subsubsection{Demographics}

In the studies conducted by Al-Ashban and Burney (2001), Karjaluoto et al. (2002) and Sathye (1999), demographic 
factor was found to be associated with different banking channels, especially IB. For instance, people with good or high educational background may have the propensity for computers and possess good information processing skills. These are critical qualities in the context of IB and therefore compound the relation between formal education and adoption. The results by Flavian et al. (2006) indicated that women were less likely to conduct their banking activities online. The findings by Akinci et al. (2004) show that middle aged consumers are more likely to use IB than younger or older consumers. Those belonging to middle class and have high level occupations are more likely to use IB. These are the results reported by Karjaluoto et al. (2002), Matilda et al. (2003) and Sathye (1999).

In Tan and Teo (2000) study, the results revealed the number of male respondents as high 80\%. Majority of the respondents were relatively young with $64 \%$ being between the ages of 20 and 29 . This was supported by Teo et al. (1999) findings that the majority of Internet users are youths and young adults. The majority of respondents were those with Bachelor's degrees (29.3\%) followed by those with secondary level of education (28.5\%). As with Tan and Teo's (2000) study, the indication is that respondents are generally of sound educational background. In terms of professions most respondents were executives (43.3\%).

As a result, the following hypothesis is proposed:

Hypothesis 1: Characteristics such as gender, age, education and occupation have significant effect on IBA.

\subsubsection{Perceived ease of use}

Amongst other authors, studies by Venkatesh (1999), Jackson et al. (1997) and Davis et al. (1989) are in support of the fact that PEOU has a significant effect on behavioral intention, either directly or indirectly through PU and attitude. In this study, such effects are reviewed in the context of IBA in Gaborone's working class and university students.

Hypothesis 2: PEOU has significant and positive influence on IBA

\subsubsection{Perceived usefulness}

This construct has been empirically proven to have the significant effect on behavioral intention by Ozdemir and Trott (2009), Gounaris and Koritos (2008), Yiu et al. (2007), Eriksson et al. (2005) Pikkarainen et al. (2004), Venkatesh (1999), Jackson et al. (1997) and Davis et al. (1989). This study hypothesizes positive linkage as follows:

Hypothesis 3: Perceived usefulness has significant and positive influence on Internet Banking Adoption (IBA)

\subsubsection{Compatibility}

Compatibility plays a major role in the diffusion of innovation. Rogers (2003:15) stated that "compatibility is the degree to which an innovation is perceived as consistent with the existing values, past experiences, and needs of potential adopters". Lack of this construct in IT with individual needs may negatively affect the individual's IT use (McKenzie 2001; Sherry 1997). Compatibility is proven to be a determinant of technology adoption in general and IB adoption specifically (Kolodinsky et al. 2004; Hernandez \& Mazoon 2007; Eriksson et al 2005). Hoerup (2001) and Tornatzky and Klein (1982) in their studies found that if innovation is compatible with an individual's needs, then uncertainty will decrease and the rate of adoption of the innovation will increase. This study intends to prove the following hypothesis on compatibility:

Hypothesis 4: Compatibility has significant and positive influence on IBA

\subsubsection{Trust}

Internet is an open network and there is high security risk involved with financial transactions (Han and Noh 1999-2000). Studies conducted by Chiemeke et al. (2006) on adoption of e-banking in Nigeria, identified major inhibiting factors to internet banking adoption as insecurity. Security risk or perceived security issues with internet banking keeps coming up as the main hindrance in the adoption of innovation in general and internet banking in particular (Mavetera \& Kesimoletse, 2007). According to Stewart (1999), the failure of the internet as a retail distribution channel has been attributed to lack of trust customers have in electronic channel and in the web merchants. Casalo et al. (2007) pointed out that trust is very critical in developing online banking. Chung and Paynter (2002), Black et al. (2002), Siu and Mou (2005), Hain et al. (2002) also reported fears regarding transaction security as an inhibitor to internet banking adoption. Gartner (2003) reports that it is important for one to build trust through long term usage of internet in general. This will in turn make it easy for one to adopt internet banking. Wang et al. (2003) reported that trust may be related to consumer judgment on security and privacy. Nevertheless, studies by Sohail and Shanmughan (2003), Eriksson et.al. (2005), Yu 
and Lo (2006) and Guerrero et al. (2007) have found a strong relationship between trust and IBA. This prompted this study to hypothesize a positive linkage as follows:

Hypothesis 5: Trust has significant and positive influence on IBA

\subsubsection{Awareness}

People need to be aware of the availability of Internet banking services before they can start using them. This was found to be a significant factor in studies done by Sohail and Shanmugham (2003). Lack of awareness was also found to be a main factor leading to customer reluctance in using online banking (Howcroft et al. 2002). This study re-evaluates these findings by analyzing the effect of awareness on IB adoption in Gaborone's working class and university students. The hypothesis is stated as follows:

Hypothesis 6: Awareness has significant and positive influence on IBA

The next section describes the research methodology employed in this study.

\section{Methodological Design}

The main intention of this study is to investigate the factors that affect IB adoption in Gaborone's working class and university students. To help address the hypotheses, the study uses a chi-square test of independence. This test helps in affiring the relationship between two or more non-mtric variables as reflected on the hypotheses statements. The testing of these hypotheses is based on $5 \%$ level of significance. The criterion is to reject the null hypothesis if the observed probability is less than the level of significance $(P<\alpha)$. This will imply that the hypothesis does not hold.

\subsection{Research Sample and Research Instrument}

\subsubsection{Sample Size}

The population for this study comprises of students from the three institutions of higher learning in Gaborone namely; University of Botswana (UB), Botho College and Limkokwing University. The other group of respondents comprise of people from Gaborone's working class. To cater for the research goals, the sample framework had to involve people with bank accounts who are aged between 18 and 65 years. The study acknowledges respondents whose age falls outside this range. Both the IB users and non-users are included in the sample. This could help the researcher to have clarity on use or non- use of Internet. A total of 100 questionnaires were distributed to these groups of people at different locations. Stratified sampling was used to achieve the required sample. The expected sample was 30 tertiary education students and 70 people from the working class. The reasons for using this sampling technique were; 1 ) it offers an easy way to obtain raw data for further analysis and 2) it is time and cost effective as it caters for random selection in the different strata. Though the use of students in this study is limited, they are good surrogate for banking customers. Current customers have experience with traditional banking services and are likely familiar with IB. Of the 100 questionnaires handed out, 89 responses were obtained indicating a return rate of $89 \%$. It must be noted that while the sample size is quite small, this does not in any way affect its representativeness to the Gaborone population at large. Hence we have used random sampling technique and considered it specifically for Gaborone area.

\subsubsection{Research Instrument}

The questionnaire used in this study consists of three parts; the first for gathering the respondents' demographic profile, the second section for collecting information about their internet and internet banking experience and the last section gathering the general comments from respondents in relation to internet. Part 2 of the questionnaire measures perceived usefulness, Part 3 asks questions about PEOU and Part 4 gathers information on habits on IB. The last part collects ideas on perceptions and attitudes about IB. Most of the questionnaire items scored on a five point likert scale.

\section{Results and Findings}

The Statistical Package for Social Sciences (SPSS) version 21 was used as the analysis tool. Results are presented as descriptive statistics on tables and chi square analysis is used to address the study hypotheses. The section below analyses and discusses the results of this study. 


\subsection{The results}

Table 1 displays a summary of socio-economic status of the respondents. Also shown are the results categorizing IB users and non-users and those intending to use it according to their socio-economic strata. These are summarized in the form of frequencies. The chi-square statistic on this table is calculated to assess the effect of demographic variable on IBA.

Table 1. Demographic profile of respondents

\begin{tabular}{|c|c|c|c|c|c|c|c|c|c|}
\hline \multirow[t]{2}{*}{ Variable } & & \multicolumn{2}{|c|}{ Responses } & \multicolumn{2}{|c|}{ Use internet } & \multirow{2}{*}{$\chi^{2}(\mathbf{P})$} & \multicolumn{2}{|c|}{ Intention to use } & \multirow{2}{*}{$\chi^{2}(\mathbf{P})$} \\
\hline & & $\mathrm{n}$ & $\%$ & $\%$ Yes & $\%$ No & & $\%$ Yes & $\%$ No & \\
\hline \multirow{2}{*}{ Gender } & Female & 43 & 48.3 & 32.6 & 67.4 & \multirow{2}{*}{$2.784(0.095)$} & 62.8 & 37.2 & \multirow{2}{*}{$8.124(0.004)$} \\
\hline & Male & 46 & 51.7 & 50.0 & 50.0 & & 32.6 & 67.4 & \\
\hline \multirow{5}{*}{ Age } & $20-30$ & 62 & 69.7 & 46.8 & 53.2 & \multirow{5}{*}{$2.957(0.228)$} & 46.8 & 53.2 & \multirow{5}{*}{$1.468(0.480)$} \\
\hline & $31-40$ & 20 & 22.5 & 25.0 & 75.0 & & 55.0 & 45.0 & \\
\hline & $41-50$ & 7 & 7.9 & 42.9 & 57.1 & & 28.6 & 71.4 & \\
\hline & $51-60$ & - & - & - & - & & - & - & \\
\hline & $61>$ & - & - & - & - & & - & - & \\
\hline \multirow{4}{*}{ Race } & Arab & 1 & 1.1 & & 100.0 & \multirow{4}{*}{$4.946(0.176)$} & 62.8 & 37.2 & \multirow{4}{*}{$5.164(0.160)$} \\
\hline & Black & 84 & 94.4 & 41.7 & 58.3 & & 32.6 & 67.4 & \\
\hline & Coloured & 2 & 2.2 & 100.0 & - & & 62.8 & 37.2 & \\
\hline & Indian & 2 & 2.2 & - & 100.0 & & 32.6 & 67.4 & \\
\hline \multirow{6}{*}{ Income } & $<P 2000$ & 35 & 39.3 & 48.6 & 51.4 & \multirow{6}{*}{$8.140(0.149)$} & 40.0 & 60.0 & \multirow{6}{*}{$6.792(0.237)$} \\
\hline & $2001-5000$ & 11 & 12.4 & 9.1 & 90.9 & & 81.8 & 18.2 & \\
\hline & $5001-10000$ & 15 & 16.9 & 53.3 & 46.7 & & 40.0 & 60.0 & \\
\hline & $10001-15000$ & 14 & 15.7 & 50.0 & 50.0 & & 42.9 & 57.1 & \\
\hline & $15001-20000$ & 9 & 10.1 & 22.2 & 77.8 & & 55.6 & 44.4 & \\
\hline & $>20000$ & 5 & 5.6 & 40.0 & 60.0 & & 40.0 & 60.0 & \\
\hline \multirow{6}{*}{ Qualification } & Junior certificate & - & - & 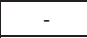 & - & \multirow{6}{*}{$2.931(0.569)$} & - & & \multirow{6}{*}{1.915 (0.751) } \\
\hline & \begin{tabular}{|l|} 
O-Level \\
\end{tabular} & 26 & 29.2 & 53.8 & 46.2 & & 42.3 & 57.7 & \\
\hline & Certificate & 9 & 10.1 & 33.3 & 66.7 & & 44.4 & 55.6 & \\
\hline & Diploma & 21 & 23.6 & 42.9 & 57.1 & & 42.9 & 57.1 & \\
\hline & Degree & 29 & 32.6 & 34.5 & 65.5 & & 51.7 & 48.3 & \\
\hline & Masters & 4 & 4.5 & 25.0 & 75.0 & & 75.0 & 25.0 & \\
\hline \multirow{4}{*}{ Occupation } & Labourer & 9 & 10.1 & - & 100.0 & \multirow{4}{*}{$10.641(0.014)$} & 77.8 & 22.2 & \multirow{4}{*}{$5.849(0.119)$} \\
\hline & Professional & 48 & 53.9 & 41.7 & 58.3 & & 50.0 & 50.0 & \\
\hline & Self employed & 2 & 2.2 & - & 100.0 & & 50.0 & 50.0 & \\
\hline & Student & 30 & 33.7 & 56.7 & 43.3 & & 33.3 & 66.7 & \\
\hline
\end{tabular}

The results show that of the 89 respondents, more than half (51.7\%) represent males. The study is dominated by youth. Most of the academics and professionals indicated an intention to use IB. Older people neither uses this media nor intends using it. These findings are consistent with Flavian et al. (2006) and Tan and Teo (2000) who reported that less females are less likely to use IB. These authors also testified that people have shown no interest in adopting this medium. Generally the respondents in this study are blacks (94.4\%) with 33.7\% representing students earning less than 2000 Pula (39.3\%). The results also reveal that the majority of respondents aged between 20 and 40 years are IB users followed by the middle aged group. Less educated people in this study use IB as compared to the more educated. It is interesting to note that both students and professionals in this study have adopted IB. These findings are supported by Teo et al. (1999) findings that the majority of Internet users are youths and young adults and have secondary level of education.

The following table summarizes the results for respondents' habits with regard to Internet usage. 
Table 2. Habits on IB usage

\begin{tabular}{|l|c|c|}
\hline \multicolumn{3}{|c|}{ Reason for internet usage } \\
\hline \multicolumn{1}{|c|}{} & $\%$ Yes & $\%$ No \\
\hline Business & 37.1 & 62.9 \\
\hline Social network and entertainment & 69.7 & 30.3 \\
\hline Study & 30.3 & 69.7 \\
\hline Banking & 22.5 & 77.5 \\
\hline Others & 31.5 & 68.5 \\
\hline Place of access & $\%$ Yes & $\%$ No \\
\hline \multicolumn{2}{|l|}{} & 24.7 \\
\hline Work & 75.3 & 68.5 \\
\hline Home & 31.5 & 84.3 \\
\hline Internet cafe & 15.7 & 53.9 \\
\hline Mobile services & 46.1 & 86.5 \\
\hline Other & 13.5 & $\%$ No \\
\hline Source of awareness & $\%$ Yes & 64.0 \\
\hline \multicolumn{2}{|l|}{} \\
\hline Banking staff & 36.0 & 85.4 \\
\hline Recommendation from others & 14.6 & 57.3 \\
\hline Advertisements & 42.7 & 84.3 \\
\hline Internet & 15.7 & 98.9 \\
\hline Other & 1.1 & \\
\hline
\end{tabular}

It is not surprising to discover that most of the respondents use internet for social network and entertainment (69.7\%) and very few use it for internet banking (22.5\%). This proves that most of the customers are either not aware of internet banking and what the benefits of this service are. Customers do access internet from their places of work (75.3\%) followed by those who use their mobile services (46.1\%) for the access. Advertising appears to be the most reliable (42.7\%) method of communication in Gaborone. Though banks do not play a significant part in making their customers aware of IB, their staff do play a very important role in the awareness campaign and should be commended for the goodjob-well done. This is supported by the $36.0 \%$ customers who use IB and got the information from banking staff (36.0\%).

\subsection{Testing of Hypotheses}

Hypothesis 1: Characteristics such as gender, age, education and occupation have significant effect on IBA.

The chi square statistic is calculated to assess the effect of demographic variables on IBA. The results of this test of independence showed that there is no significant difference between the selected demographic variables such as gender $\left(\chi^{2}=2.784 ; p>0.05\right)$, age $\left(\chi^{2}=2.957 ; p>0.05\right)$ and education $\left(\chi^{2}=2.931 ; p>0.05\right)$ and IB users. Also confirmed is the fact that these demographic variables are significantly related to respondents' intention to adopt IB. These results confirm Al-Ashban and Burney (2001), Karjaluoto et al. (2002) and Sathye (1999)'s findings as discussed earlier. However, the results of this study are inconsistent with these author's findings in reference to effect of occupation $\left(\chi^{2}=10.641 ; p<0.05\right)$ and current IB users. The study revealed that occupation does not have a positive influence on people's intention to adopt IB. This inconsistency will be discussed in later sections.

Hypothesis 2: PEOU has significant influence on IBA

Table 3. Effect of PEOU on IBA

\begin{tabular}{|l|c|c|}
\hline Statement & $\chi^{2}$ & $\mathrm{P}$ \\
\hline IB is easy to use & 7.317 & 0.062 \\
\hline Website is easy to navigate & 5.726 & 0.221 \\
\hline
\end{tabular}

The chi-square results show that PEOU has a significant effect on IBA $(p>0.05)$. These results are supported by findings from studies by Venkatesh (1999), Jackson et al. (1997) and Davis et al. (1989) that PEOU has a significant effect on behavioral intention to use IB. 
Hypothesis 3: PU has significant and positive influence on Internet Banking Adoption (IBA)

Table 4. Effect of PU on IBA

\begin{tabular}{|l|c|c|}
\hline Statement & $\chi^{2}$ & $\mathrm{P}$ \\
\hline Do you think using internet is necessary? & 8.256 & 0.083 \\
\hline Do you think internet banking is convenient? & 0.818 & 0.936 \\
\hline Do think internet banking is cost effective? & 6.469 & 0.167 \\
\hline
\end{tabular}

As the results indicate, PU has a significant effect on IBA. These findings are consistent with those confirmed by the studies previously undertaken by Ozdemir and Trott (2009), Gounaris and Koritos (2008), Yiu et al. (2007), Eriksson et al. (2005) Pikkarainen et al. (2004), Venkatesh (1999), Jackson et al. (1997) and Davis et al. (1989).

Hypothesis 4: Compatibility has significant and positive influence on IBA

Table 5. Effect of compatibility on IBA

\begin{tabular}{|l|c|c|}
\hline Statement & $\chi^{2}$ & $P$ \\
\hline Do you have access to internet? & 0.417 & 0.518 \\
\hline How often do you access internet? & 6.421 & 0.170 \\
\hline How long do you use internet per day? & 18.588 & 0.001 \\
\hline
\end{tabular}

As revealed on Table 5, access to internet and frequency of internet usage has a significant and positive influence on IBA $(p>0.05)$. However, the duration of internet usage appears to be not significantly related to $\operatorname{IBA}(p<0.05)$. This study partially concurs with the findings generated in studies conducted by Kolodinsky and Hilgert (2004), Hernandez and Mazoon (2007), Eriksson et al. (2005), Hoerup (2001), and Tornatzky and Klein (1982) which proved innovation being compatible with an individual's needs and the rate of adoption. However, duration of internet use does not support the hypothesis $(P<0.05)$. If compatibility is defined as the degree to which innovation fits the adopters' work habits, then, it is noted that Internet access times and durations are very limited in Botswana due to some negative socio-economic factors. Very few people can afford to access the internet because it's considered an unnecessary luxury item.

Hypothesis 5: Trust has significant and positive influence on IBA

Table 6. Effect of trust on IBA

\begin{tabular}{|l|c|c|}
\hline \multicolumn{1}{|c|}{ Statement } & $\chi^{2}$ & $\mathrm{P}$ \\
\hline Do you trust internet banking & 3.050 & 0.549 \\
\hline Do you think that your transaction can be completed very well through the internet? & 3.544 & 0.471 \\
\hline Would you recommend internet banking to others? & 5.413 & 0.247 \\
\hline
\end{tabular}

As publicized on Table 6, trust does play a very important role in the customer's decision to adopt IB $\left(\chi^{2}=3.050 ; p>0.05\right)$ $\left(\chi^{2}=3.544 ; p>0.05\right)$ and $\left(\chi^{2}=5.413 ; p>0.05\right)$. These findings correspond with those from Liao et al. (2003), Eriksson et al. (2005), Yu and Lo (2007) and Guerrero et al. (2007) who also found that trust has a strong relationship with IBA.

Hypothesis 6: Awareness has significant and positive influence on IBA

Table 7. Effect of awareness on IBA

\begin{tabular}{|l|c|c|}
\hline \multicolumn{1}{|c|}{ Statement } & $\chi^{2}$ & $P$ \\
\hline Are you aware of the availability of internet banking? & 2.635 & 0.105 \\
\hline Do you think the banks are doing enough to make people know about internet banking? & 11.768 & 0.019 \\
\hline
\end{tabular}

Table 7 displays the results confirming the significant effect of customer's awareness $\left(\chi^{2}=2.635 ; p>0.05\right)$ on IBA. However, it appears that banks are not doing enough on creating awareness to their customers about IBA $\left(\chi^{2}=11.768 ; p<0.05\right)$. This study results are somewhat consistent with those obtained by Sohail and Shanmugham (2003) and (Howcroft et al. 2002) who discovered that lack of awareness is the main factor leading to customer reluctance in using online banking. There 
could be a factor also of many people not being quite affluent and hence they do not know whether banks are marketing the IB services or not?

\subsection{Findings}

This study results confirms the findings by Flavian et al. (2006), Tan and Teo (2000) and Teo et al. (1999) in relation to the demographic profiles of respondents. The only inconsistency concerning this construct is that the type of occupation does not have a significant influence on customer's decision to adopt internet banking. This is in stuck contrast to the view that good occupational levels are positively related to the level of education. Other constructs, PEOU, PU, compatibility, trust and awareness are confirmed to be significantly and positively related to IBA, although findings on compatibility and awareness do show some inconclusiveness on some constructs investigated. However, the study confirms the reports made by other authors such as Kolodinsky et al. (2004); Hernandez and Mazoon (2007), Eriksson et al. (2005), Hoerup (2001), Tornatzky and Klein (1982), Sohail and Shanmugham (2003) and Howcroft et al.( 2002).

\section{Concluding Remarks}

This study integrated the TAM and IDT to build the IBA model. The model was used to analyses the adoption of internet banking among Gaborone's working class and university students. The empirical results show that PEOU, PU, and trust have significant influence on IBA. One important finding is that among the demographic profiles, gender and occupation are not important indicators of IBA in connection with customers intending to use and adopting IB. Compatibility and awareness are confirmed to be measures of IBA but with caution. To lure customers into adopting internet banking, bank managers should direct efforts and resources in the most effective and efficient way to increase banking business hours in future and encourage them to adopt IB. To help address the problem of compatibility, banks may have to increase the number of IB terminals they have in their banking halls where customers especially those with limited or no access to internet will be able to use internet for as long as they wish. The usage will be at the cost of the client. There are several studies that have been done in the field of IBA. However, while most of them are confirmatory type of studies like this one, the strength of our study lies in the integration of constructs from both TAM and IDT. Furthermore, there are very few studies that look at the acceptance or rejection of a hypothesis focusing entirely on the probability of occurrence (p-value) as shown in this study.

Additionally, the study was not designed to be overly complicated, hence it can be replicated by novice researchers especially those doing their honors degrees or MBA studies. One of the strength of the study as teaching and learning tool is its ability to support every argument with some authoritative sources. Many studies are deficient in this area. Lastly, instead of taking a confirmatory approach to behavioral studies like this one, the authors would like to suggest that an exploratory study maybe more appropriate with structural equation modeling as the preferred analysis technique. This can reveal more insights into the data. However, if this is to be done, the sample size needs to be increased. Sample size is one of the weakness of this study hence we cannot generalize the findings to the whole of Botswana.

\section{References}

Ainin, S., Lim, C. H. and Wee, A. (2005). Prospects and challenges of E-banking in Malaysia. The Electronic Journal on Information Systems in Developing Countries, 22, 1, 1-11.

Azjen, I. (1991). The Theory of Planned Behavior. Organizational Behavior and Human Decision Processes, 50, 179-211.

Black, N.J., Lockett, A., Winklhofer, H. and McKechnie, S. (2002). Modeling consumer choice of distribution channels: an illustration from financial services. The International Journal of Bank Marketing, 20, 4, 161-173.

Casalo, L. V., Flavian, C., and Guinaliu, M. (2007). The role of security, privacy, usability and reputation in the development of online banking. Online Information Review, 31, 5, 583.

Chiemeke, S. C, Evwiekpaefe A.E. and Chete, F.O. (2006). The Adoption of Internet Banking in Nigeria: An Empirical Investigation. Journal of Internet Banking and Commerce, 11, 3.

Chung, W. and Paynter, J. (2002). An Evaluation of Internet banking in New Zealand. Proceedings of the 35th Annual Hawaii International Conference on System Sciences, 2410-2419.

Daniel, E. (1999). Provision of electronic banking in the UK and the Republic of Ireland. International Journal of Bank Marketing, 17, 2, 72-82.

Davis, F. D. (1986). A technology acceptance model for empirically testing new end-user information systems: Theory and results, Doctoral dissertation, Sloan School of Management, Massachusetts Institute of Technology.

Davis, F.D., Bagozzi, R. and P.R. Warshaw (1989). User acceptance of computer technology. Management Science Journal, $35,8,982-1003$. 
Eriksson, K., Kerem, K. and Nilsson, D. (2005). Customer acceptance of Internet banking in Estonia. The International Journal of Bank Marketing, 23, 2/3, 200-216.

Gartner, (2003). Gartner Says Banks Must Focus on Online Financial Applications to Remain Competitive in 2003 and Beyond, Press Release, Gartner Group, February 20.

Gounaris, S. and Koritos, C. (2008). Investigating the Drivers of Internet Banking Adoption Decision A Comparison of Three Alternative Frameworks. International Journal of Bank Marketing, 26, 5, 282-304.

Guerrero, M.M., Egea, J.M.O. and Gonzalez, M.V.R. (2007). Application of the latent class regression methodology to the analysis of Internet use for banking transactions in the European Union. Journal of Business Research, 60, 137-145.

Hain, D., Tootell, H. and Alcock, C. (2002). Understanding attitudes towards Internet banking. Proceedings of Collector 2002. Seventh Annual Collector Conference on Electronic Commerce, Melbourne, Australia.

Han, K. S. and Noh, M. H. (1999-2000). Critical Failure Factors That Discourage the Growth of Electronic Commerce. International Journal of Electronic Commerce, 4, 2, 25-43.

Hernandez, J. and Mazzon, J. (2007). Adoption of internet banking: proposition and implementation of an integrated methodology approach. Marketing, 25, 2, 72-88

Hoerup, S.L. (2001). Diffusion of an innovation: computer technology integration and the role of collaboration, Doctoral dissertation, Virginia Polytechnic Institute and State University, 2001. ProQuest DigitalDissertations, UMI AAT 3031436.

Howcroft, B., Hamilton, R. and Hewer, P. (2002). Consumer attitude and the usage and adoption of home-based banking in the United Kingdom. The International Journal of Bank Marketing, 20, 3, 111-121.

Jackson, C.M., Chow, S. and Leitch, R.A. (1997). Toward an understanding of the behavioral intention to use an information system. Decision Sciences, 28, 2, 357-389.

Jayawardhena, C. and Foley, P. (2000). Changes in the banking sector: the case of internet banking in the UK, Internet Research: Electronic Networking Applications and Policy, 10, 1, 19-30.

Karjaluoto, H. (2002). Selection criteria for a mode of bill payment: Empirical investigation among Finnish bank customers. International Journal of Retail and Distribution Management, 30, 6, 331-339.

Karjaluoto, H., Mattila, M. and Pento, T. (2002). Factors underlying attitude formation towards online banking in Finland. International Journal of Bank Marketing, 20, 6, 261-72.

Khalil, M.N. and Pearson, J. M. (2007). The influence of trust on internet banking acceptance. Journal of Internet Banking and Commerce, 12, 2, 1-10.

Kolodinsky, J.M., Hogarth, J.M. and Hilgert, M.A. (2004). The adoption of electronic banking technologies by US consumers. The International Journal of Bank Marketing, 22, 4, 238- 245.

Lichtenstein, S. and Williamson, K. (2006). Understanding consumer adoption of internet banking: An interpretive study in the Australian Banking Context. Journal of Electronic Commerce Research, 7, 2, 50-66.

Mattila, M., Karjaluoto, H., and Pento, T. (2003). Internet banking adoption among mature customers: early majority or laggards? Journal of Services Marketing, 17, 5, 514-528.

Mavetera, N. and Kesimolotse, M.G. (2007). Issues Affecting the Adoption and Continual Usage of Internet Banking Services in South Africa, In Managing Worldwide Operations and Communications with Information Technology, M. Khosrow-Pour (eds.) Proceedings of 2007 Information Resources Management Association, International Conference, May 19-23, Vancouver, British Columbia, Canada, CD ISBN: 978-159904930-4.

McKenzie, J. (2001). Perform or Else: From Discipline to Performance. New York: Routledge.

Mols, N. (1998). The Behavioural Consequences of PC banking. International Journal of Bank Marketing, 16, 5, $195-201$.

Ndubisi, N. O. and Sinti, Q. (2006) Consumer attitude, system's characteristics and internet banking adoption in Malaysia, Management Research News, 29, 1/2, 16-27.

Ozdemir, S and Trott, P. (2009). Exploring the adoption of a service innovation: A study of Internet banking adopters and non-adopters. Journal of Financial Services Marketing, 13, 4, 284-299.

Pikkarainen, T., Pikkarainen, K., Karjaluoto, H. and Pahnila, P. (2004). Consumer acceptance of online banking: An extension of the technology acceptance model. Internet Research, 14, 3, 224-235.

Rogers, E.M. (1995). Diffusion of innovations, New York: Free Press.

Ross, S.A. (1973). The economic Theory of Agency: The Principal's Problem. American Economic Review, 63, 2, 134-139.

Rotchanakitumnuai, S. and Speece, M. (2004). Corporate customer perspectives on Business value of Thai Internet Banking. Journal of Electronic Commerce Research, 5, 4, 270-286.

Sathye, M. (1999). Adoption of Internet banking by Australian consumers: an empirical investigation. International Journal of Bank Marketing, 17, 7, 324-334.

Sherry, L. (1997). The Boulder Valley Internet Project: Lessons learned. The Journal. (Online) http://www.theiournal.com/magazine 197/sep/feat5.html

Siu, N.Y-M., and Mou, J. C-W. (2005). Measuring Service Quality in Internet Banking: the Case of Hong Kong. Journal of International Consumer Marketing, 17, 4, 97-114.

Sohail, M.S. and Shanmugham, S. (2003). E-banking and customer preferences in Malaysia: An empirical investigation. Information Sciences, 150, 3-4, 207-217.

Stewart, K. (1999). Transference as a means of building trust in World Wide Web Sites Proceedings of the 20th ICIS, Charlotte, North Carolina. 
Taylor, T. and Todd, A.P. (1995). Understanding Information Technology Usage: A Test of Competing Models. Information Systems Research, 6, 2, 144

Tornatzky, L.G.and Klein, K.J. (1982). Innovation characteristics and innovation adoption implementation: A meta-analysis of findings. IEEE Transactions on Engineering Management, 29, 1, 28-44.

Turkey, Onar, S. C., Aktas, E. and Y.I. Topcu, Y.I. (2010). A Multi-Criteria Evaluation of Factors Affecting Internet Banking in Turkey. Multiple Criteria Decision Making for Sustainable Energy and Transportation System. Lecture Notes in Economics and Mathematical Systems, 34, 235-246.

Venkatesh, V. (1999). Creation of favorable user perceptions: Exploring the role intrinsic motivation. MIS Quarterly, 23, 2, $239-260$.

Wang Y., Lin H. and Tang, T. (2003). Determinant of user acceptance of Internet Banking: an empirical Study. International Journal of Service Industry Management, 5,501-518.

Yiu, C. Grant, K. and Edgar, D. (2007). Factors Affecting the Adoption of Internet Banking in Hong Kong- Implications for the Banking Sector. International Journal of Information Management, 27, 336-351.

Yu, C.S. and Y.F. Lo, Y.F. (2007). Factors encouraging people to adopt online banking and discouraging adopters to use online banking services. Proceedings of International Conference on Business and Information. Tokyo, Japan. 